\title{
A Century of Instability in Housing Finance in the United States
}

\author{
John C. Edmunds ${ }^{1 *} \&$ Mark F. Lapham ${ }^{1}$ \\ ${ }^{1}$ Finance Department, Babson College, Wellesley, USA \\ *John C. Edmunds, E-mail: edmunds@babson.edu
}

Received: October 14, 2016

Accepted: November 10, 2016 Online Published: November 24, 2016

doi:10.22158/jepf.v2n2p360

URL: http://dx.doi.org/10.22158/jepf.v2n2p360

\begin{abstract}
The U.S. housing sector, including housing starts, house purchasing, and the institutions involved in financing house purchases, has been unstable for most of the past century. We divide the years since 1920 into periods and study the instability for each period. We found that there was no Golden Age of stability in the sector. Instead, the time intervals that we studied were each characterized by metrics of instability that were equal within a reasonable margin of error. These results imply that the U.S. has built a stock of housing and has succeeded in making home ownership an attainable dream, but that accomplishment is overshadowed by the frequent booms and busts. In a second paper we intend to examine the effects on economic growth and recessions that have been associated with the instability in the housing sector. The social costs of instability have been large, and our estimate will be intended to provoke debate and further research.
\end{abstract}

\section{Keywords}

housing starts, mortgage financing, boom and bust, volatility, United States mortgage industry

\section{Introduction}

For the past century home-building and home ownership have been strongly associated with periods of sustained economic growth in the US, but downturns in home-building have often been blamed for periods of slow or negative economic growth. For the past seven years, the slow, sputtering recovery of home-building and home ownership has been cited as one of the underlying reasons why the U.S. economic recovery that began in March 2009 has been so sluggish. It has also been argued that the housing market might have recovered more quickly after 2009 if foreclosure procedures had produced outcomes more quickly, but the mortgage market was also slow to recover.

Data on housing starts, available from 1920 onward, indicates that the current severe downturn in housing construction and ownership is only the most recent chapter in a long history of volatility. Data from the 1920s to the present day indicate that the United States has struggled to create a system for financing home purchases. Demographic data indicate the demand for housing should have been predictable, but home-building and purchases were nevertheless unstable. A review of the financial 
practices suggests some possible reasons for the instability. For the decades before World War II, financing for home buyers was frequently unavailable, and when it was available, it was on terms that often proved unfavorable to the home buyer. This spotty, bumpy performance is disturbing and has proved surprisingly difficult to remedy. For comparison, one can consider the financing institutions to the legal system for adjudicating disputes about property lines and ownership claims. That may be an unfair comparison, because it might be easier to adjudicate disputes about ownership of land than to finance the purchase of houses. Nevertheless, the legal system appears to have reached a satisfactory degree of stability much earlier. The practices of transferring title to property functioned smoothly for most of the past century. The legal system also could, during most of the years since 1920, handle foreclosures in routine fashion. The crisis of 2008-2009 revealed, however, that the systems did not work equally well in all the states. The sudden jump in the number of foreclosures overloaded the processing capability.

There has been political will to improve the conventional ways of financing home purchases. Starting in the Thirties, Congress authorized the creation of the Federal Housing Administration and the United States Housing Authority. These entities sought to improve availability of housing and also worked with financial intermediaries to increase the pool of mortgage funds. After World War II there were more initiatives, and for the immediate post-war years, financing was more abundant and the terms were better suited to the buyers' income and net worth. The interest-only mortgage loans gave way to the amortizing loans, so that after twenty or twenty-five years the buyer could own the house free of debt. In those ways there was progress toward making the residential financing sector more accommodating and accessible to middle-class buyers whose parents had not been able to own their own home. Conventional practices after World War II were easier for new buyers than the archaic methods in use by traditional financial intermediaries before World War II, but conventional financing practices did not continuously evolve and develop as smoothly and efficaciously as the legal system for recording and reporting ownership.

In this paper we focus on the variability in the construction and purchases of houses in the United States from 1920 onward. We find that for the entire period home building has experienced booms and busts, and that there have been prolonged periods of depressed activity, interspersed with brief, giddy periods of boom, followed by overbuilding, bankruptcies and foreclosures. For expository purposes we divide that time frame into the decade of the Twenties, the decade of the Great Depression, and three post-World War II eras: from 1945 to 1971; from 1972 to 2008; and from 2009 to the present. To characterize each of the three post-World War II eras, we label them as the savings-bank era, the deregulation, consolidation and securitization era, and the post-crisis prudent era. We describe quantitatively each of the pre-World War II decades, and each of the three post-war eras and argue that the country's overall record of achievement is less than fully satisfactory. Each time frame that we studied displayed a degree of volatility greater than our casual preconception prepared us for. We expected that housing finance had been relatively stable for some periods of time in the country's past. 
But the data did not support our rose-tinted preconception. On the most macro scale, Americans became homeowners, but the path was never smooth. The nation's accomplishment was that millions of households were able to buy their own home and pay off the mortgage. Home ownership indeed did increase in the decade before the Great Depression, and again after World War II. A quantum leap in home ownership occurred in the three eras after World War II. For the Twenties and Thirties homeownership hovered around 45\%; the quantum leap was in the years immediately following 1945. By 1950 home ownership had already leaped up to 55\% of households. From there it rose to $66 \%$ in 2000.

That gain in home ownership was an accomplishment, but it came at a disturbingly, and probably unnecessarily high cost. The cost was volatility in home building and home buying, during a time period when trends in household formation were clear enough to allow for much steadier activity in construction and purchases. The less visible cost was incomplete coverage of all demographic groups. It was presumably a social objective that all households should have equal access to home ownership. Yet there were many demographic groups and geographical regions within the United States that did not have as much access to financing as the national norm. In the sequel to this paper, we compute estimates of the cost of both of these imperfections in the system's performance. The cost of each imperfection is measured relative to potential GDP for each year. In the second paper we attempt to show that because of the volatility, economic growth was slower and more unstable than was theoretically possible. We propose to compute the lost economic growth as a percent of GDP each year. There were years when growth was raised by booms in home-building and purchases, but there were more years when home-building and home-buying were below their ideal level, and in those years, economic growth was lower that it would have been if the financing had been steadily available. For the incomplete coverage, we identify a relatively deprived demographic and compute what the increase in GDP would have been if that group had been more fully able to obtain financing to purchase houses. There were losses in addition to those two, for example the cyclical unemployment of workers in residential construction, and the human cost of evictions and foreclosures. Our analysis does not attempt to quantify those losses; the two losses that we compute are sufficiently large to indicate the cost of our underperforming financial services sector.

The papers in this series are as follows. In the first paper we give a quantitative overview of the entire 1920-2016 time period of housing finance in the United States, and quantitative details of the accomplishments and failures of each of the two pre-World War II decades, then each of the three de facto housing finance systems that operated in each of the three post-World War II eras. In the second paper we compute the lost economic growth that the de facto mechanisms have caused. Then in the third paper of this three-part series we propose new ways of financing home buying, attempting to reinvigorate successful elements of the three de facto mechanisms. 


\section{Housing Finance in the United States 1920-2016}

Housing finance has become intertwined with the aspirations of the broad middle of the American socio-economic strata. It is the means by which most home buyers succeed in purchasing homes. It has played a pivotal role in building nest eggs for millions of people. It has also fueled speculative bubbles and has derailed the lives of many former homeowners.

The Twenties and the Thirties began with a steep climb, followed by an even steeper plunge. The finance sector was caught up in the rise and can be accused of financing the overbuilding in Florida that came down in 1926. The finance sector can also be accused of setting the stage for the Great Depression. But the finance sector was not in the role of steward of the nation's financial stability. The sector consisted of private firms, each operating according to its own practices. Supervision came starting in 1933, and it was not until 1946 when the Congress formally made full employment and macroeconomic stability into expressed national goals. It is, therefore, inappropriate to criticize the sector for providing varying amounts or inadequate amounts of financing to home buyers. The sector was a decentralized aggregation of entities that did not have overarching social goals nor a formal hierarchy above the level of the boards of directors of the individual institutions. Housing finance in the Twenties and Thirties was, when viewed in reference to the standards of its time, neither successful nor unsuccessful. It made lending decisions on a case-by-case basis, without formally considering its macro impacts, and without altering its decisions to achieve broad social objectives.

Housing finance can be called successful in the post-World War II era because it raised homeownership from $55.0 \%$ in 1950 to $66.2 \%$ in 2000 and $66.1 \%$ in 2010 . It reversed a decline in homeownership that spanned the Depression, dropping the rate of home ownership from $45.6 \%$ in 1920 to $43.6 \%$ in 1940. The rate of home ownership reached 69\% in 2007 but subsequently came down hard and fell as low as $64.5 \%$ by 2014. That bruising decline was not the only traumatic housing debacle that the U.S. suffered in the post-World War II time frame. There were others in 1956-1957, 1966-1967, 1974-1975, 1981-1982, and 1990-1991, before the calamitous unraveling of 2008-2009.

The high level of home ownership came at the cost of violent swings in home-building, so that construction workers could not count on stable employment. Homeowners also had to cope with wide bipolar swings in homeowners' equity. Investors and institutions that financed home construction and purchases also had to cope with volatile returns, defaults, and threats of financial contagion. In seeking ways of improving performance, it is useful to compute indicators of volatility for each of the two decades before World War II and for the three eras of post-World War II housing finance that we identify. If there is one era, or one channel that is characterized by greater stability, it will be worthwhile to consider why. But if all the time periods we studied are unstable in approximately the same degree, there would need to be further research to determine whether the instability is from exogenous sources. 


\section{Volatility Track Record}

\subsection{Housing Finance in the United States 1920-1939}

Housing finance in the United States in the 1920s was erratic and less abundant than the period of high economic growth and investment would indicate. Finance flowed to industry and infrastructure, and to residential construction in smaller proportion. The growth companies of the 1920s were U.S. Steel, ATT, Radio Corporation of America, and General Electric. Projects to build roads, transmission lines, pipelines, and electric streetcars competed successfully for the available pool of funds. It was a pre-modern version of "crowding out" - the highly-rated borrowers in the industrial sector could borrow and soak up the funds that otherwise might have gone to residential construction. A countervailing force was urbanization. As workers moved to the cities, housing had to be built to accommodate the new arrivals. Suburbs also grew during the 1920s. In that was residential construction facilitated the growth of cities and accelerated the depopulation of the countryside by making it easier to move from the countryside to the city.

The net effect of the dynamic shifts of population is that home ownership rose from $45.6 \%$ of households in 1920 to $47.8 \%$ in 1930 . That might sound gradual, but it masks a volatile decade. Housing starts per 1000 people were as low as 10.0 in 1920, shot up to 34.0 in 1925, then sagged down to 17.2 in 1929.

Home building in the 1930s was depressed during the entire decade. For example, housing starts per 1000 people were below 10 for the years 1931-1936. Starts finally struggled up to 14.9 in 1939. If twice as many houses had been started each year, the performance would still have been less than the average for the 1920s. Clearly there was lost output - in part due to the lack of stable jobs that would allow a wage-earner to pay a mortgage, and in part due to the chronic underperformance of the financial services sector during that traumatized decade. Many houses were not built, and the jobs for construction workers were not created. From the vantage point of eight decades later, it is difficult to know how many houses might have been built if the financial system had been able to function more in keeping with the patterns that had been established in previous and subsequent decades.

The overall view of housing starts in the Twenties and the Thirties is that both decades were unstable within each decade. Home building went through a boom in the middle years of the 1920s. Housing starts rose from 247,000 in 1920 to 937,000 in 1925 , and then fell back to 509,000 in 1929. In the Thirties, despite the gloom hanging over the entire decade, there was a similar amount of volatility. Housing starts ranged from a meager 93,000 in 1933 to a less-than-robust 515,000 in 1939.

\subsection{Post-World War II Volatility}

How volatile has U.S. housing finance been since World War II? Has there really been a period when it was stable, and a later period when it was disrupted? Has investment in residential real estate been associated with booms and recessions in GDP growth? The graphs below track Housing Starts and Percentage Change in real GDP over the period 1945-2015. It is tantalizing to note that strong Housing Starts (1.3 million units or more) always preceded or accompanied strong (3\% or higher) growth in real 
GDP for the years of the post-World War II period. It is also clear that the steep drop in housing starts and the painfully slow rebound from the financial crisis of 2008 was accompanied by the anemic growth of GDP over the period since 2008. This rebound of homebuilding and home-buying was sluggish despite multiple attempts by government agencies to accelerate the rebound.

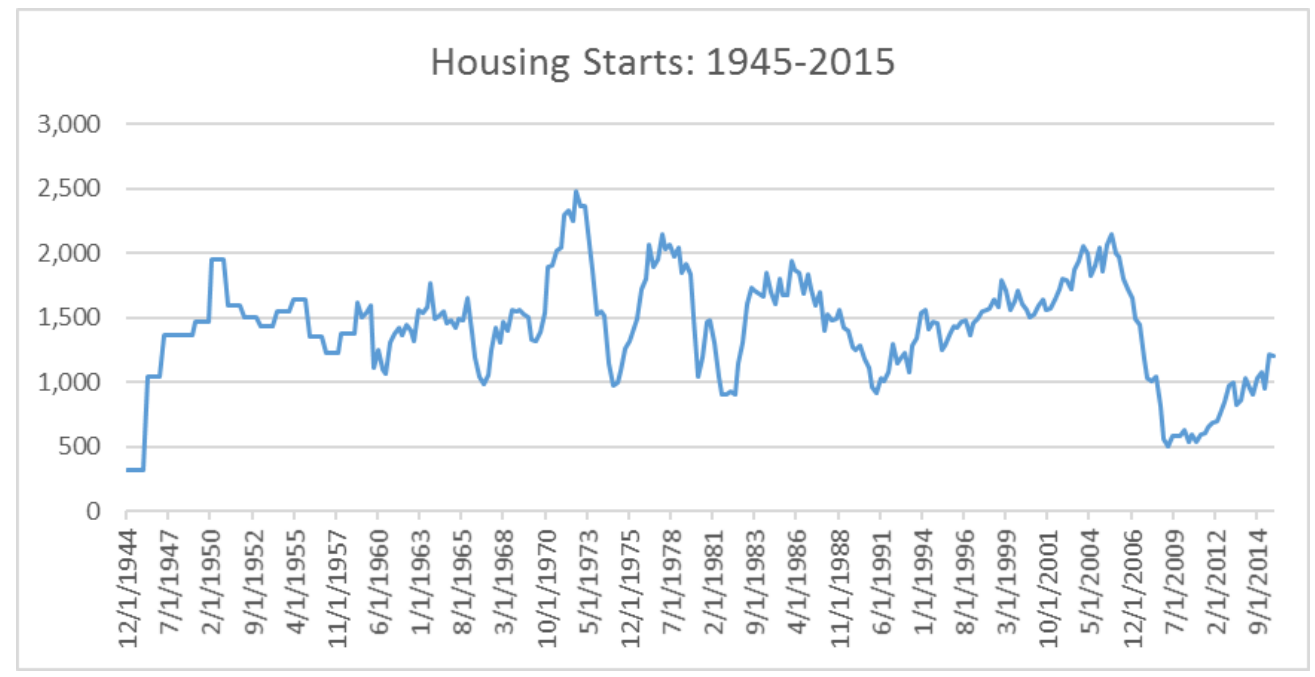

Figure 1. Housing Starts: 1945-2015

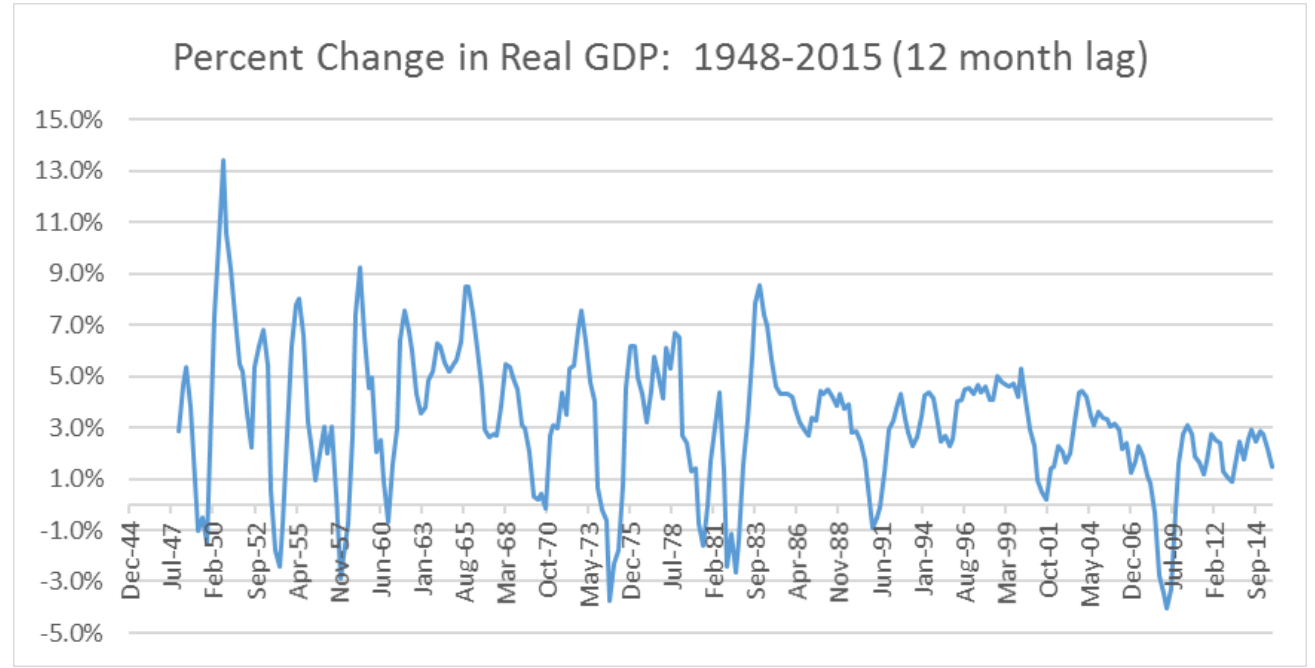

Figure 2. Percent Change in Real GDP: 1948-2015 (12 Month Lag)

For a cursory look at how volatile the two eras were, we computed the standard deviations of housing starts for 1945-1971 and for 1972-2008. These results are 313,579 starts for 1945-1971, 349,538 for 1972-2008, and 215,848 for 2009-2015. Superficially, those figures imply that the era of decentralization, consolidation and securitization was characterized by more volatility than the savings bank era. The difference, however, is small and subject to error because for 1945-1959 we used annual data, and for 1960-2015 we used quarterly data. Also the standard deviations should be compared to the 
annual averages for the three eras, and when we do the comparison that way, the results are even less conclusive. The savings bank era and the deregulation, consolidation and securitization eras were about equally volatile. The most volatile era relative to its average was the post-crisis prudent era. That result, however, is due to the very depressed level of housing starts for the years 2009-2015. The data show high volatility because housing starts rose sharply as the sector recovered, so its standard deviation can be seen as a metric of the leaps upward that housing starts displayed. For the post-crisis years average annual housing starts were only 794,440 , rising from barely over 500,000 to over $1,200,000$. The average for the post-crisis period was only about half the average for the years 1945-1971 and 1972-2008.

These standard deviation calculations reveal that there has not been an era of housing finance in the United States that was decidedly more stable than any other. There are people who speak fondly of the savings bank era, perhaps because it was superior to the pre-World War II pattern of housing finance. But that is an unfair comparison. Prior to the Housing Act of 1937, the de facto policy of the United States was to leave housing finance to the private sector. Therefore, it is to be expected that housing finance in the 1920s and 1930s would have been a spotty hodgepodge of ups and downs that most certainly were ramped up during the 1920s and drastically curtailed in the 1930s. So the savings bank era was productive, in terms of housing units that were constructed, but for home buyers and investors and institutions financing home buyers, that era was as much a roller-coaster ride as any of the others.

\section{The Savings Bank Era, 1945-1971}

As a way of illustrating the long, complicated history of the U.S. financial system, and the ways the U.S. has provided mortgage financing, we trace the rise and fall of the savings banks (thrifts), and we discuss the reasons for their success and their eclipse. The rhetorical starting point of our discussion is that thrifts played a central role in the wave of home ownership that began in the 1940's, continued in the 1950's and 1960's. The thrifts were a variable source of financing during the period 1945-1970, but they did not lose their dominant role until the 1970s, when they were vulnerable to maturity mismatch during the waves of inflation that characterized the years 1973-1980. The thrifts were providers of "community banking" style intermediation, in which middle-class couples bought homes by borrowing the savings of the communities where they lived. The lending officer for mortgage loans from thrift institutions was, in those bygone days, their neighbor or a person in their own community.

The pattern of housing finance was in step with the policy of community-level banking that emerged following the 1929 stock market crash. The financial reforms of the New Deal explicitly mandated that financial intermediaries were to be local. These reforms took different routes in each state to achieve a large, viable population of small banks that operated in towns and secondary cities. In the Midwest, many states were "unit banking" states, meaning that a bank could have only one office. In the Northeast, the rules were slightly different but the result was the same. Massachusetts, for example, allowed banks to expand only within the county where their headquarters was located. Advocates of 
this granular approach to banking point to its success in fostering home-building and home ownership. Before 1929, the banking sector was concentrated, and big banks in the cities could attract the savings of small communities. The dominant view in the early 1930s was that the large banks starved the small towns and rural areas of credit, so home buyers could not obtain financing. That view, combined with the country's long history of distrust of financial intermediaries, provided motivation for local-to-local lending and borrowing. The citizenry's distrust of centralized financial intermediation was a core tenet of Thomas Jefferson's thinking and predated the War of Independence. One of the underlying objectives of the New Deal reforms was to break up the big banks, and foster local lending. To diminish the advantages large banks had, states and the Federal government imposed restrictions that favored small institutions. Three illustrations of these restrictions will characterize the ways that governments and regulators mandated the market should be compartmentalized along geographic lines, and blunted the advantages that consolidated financial firms could have. First, the states imposed restrictions on how many branches a bank could have. Some Midwestern states became "unit banking" states - meaning a bank could have only one office in that state, and could not create branch offices outside the state. Second, most lenders were prohibited from issuing a mortgage on a house more than 50 miles from their office. And third, Regulation Q prevented banks from competing aggressively for funds.

To continue with this rhetorical depiction of the thrift era, the U.S. financial system, as reconstituted after the Great Depression, worked very well to finance home ownership in 1946-1950, the immediate post-World War II years. The system not only performed its role, but also did so without destabilizing other parts of the financial system, and without triggering any international financial crises. Its performance in the 1950s and 1960 was much spottier. Then from 1971 onward, the intermediaries that finance home purchases suffered both neglect and regulatory defeats that gradually crippled their ability to supply financing for homebuyers. The year 1971 was also when the Bretton Woods systems of international payments came unraveled. Bretton Woods gave the U.S. dollar an exalted role, and that might have increased the willingness of lenders to provide long-term fixed-rate mortgages. These regulatory defeats, and losses on their portfolios of long-term, low-interest mortgage loans, almost put the traditional housing lenders out of business. This friendly, easy-to-understand source of financing for home purchases has not recovered. What replaced it was the securitization era, which was not a wellspring of sustainable economic growth, but instead a source of volatility, a driver of boom-and-bust cycles, vulnerable to crisis, and predisposed to fuel financial bubbles.

Is that characterization of these two eras accurate? Was housing finance stable during the thrift era, and then unstable during the securitization era? To be generous, we share the widely held view that housing finance was unstable but largely successful, at least on its own terms, in the period 1945-1970. For the post-1971 period, the weight of expert opinion is more critical. The accusations are that housing finance was unstable and pro-cyclical from 1971 onward. For the post-crisis prudent era, the institutions were successful in imposing very strict underwriting standards, so loan losses on new 
credits have been low; but the low volume of lending clearly fell short of what was needed to finance the higher levels of home buying that would have sparked a stronger economic recovery in the U.S.

\section{The Era of Deregulation, Consolidation and Securitization}

The pattern of mortgage origination changed in the first years of the 1970s. Commercial banks, savings banks and cooperative banks began to sell the mortgages they originated. There had been a few cases in previous decades of mortgage lenders who sold their loans, or originated loans that were going to be guaranteed by a government agency. But the big event was the creation of GNMA pass-through securities. Those appeared in 1970, and we have chosen 1971 as the last year of the savings bank era. The issuance of mortgage-backed securities took off, from less than $1 \%$ of residential mortgages outstanding, to over $6 \%$ by 1975 . Savings banks held over $55 \%$ of outstanding single family mortgages in 1970 , but by 1990 savings banks' market share had declined to $22.9 \%$, of outstanding single family mortgages, and continued to decline to $11.9 \%$ by 2000 . The market share of mortgage-backed securities rose sharply, reaching $50.5 \%$ by 1995 .

Well before the formal starting date for securitization, deregulation was already creeping in. The formal restrictions imposed during the worst days of the Depression remained in effect for decades after the end of World War II. During the 1950s and the 1960s there was a tacit truce between the advocates of community banking and the advocates of centralization and economies of scale. With respect to the perennial tug-of-war between the financial regulators and the financial services firms, the Fifties and Sixties were quiet. Bankers and the larger community accepted the system they had inherited from the Depression years because it performed well enough in comparison with the system that they remembered from before the War.

There were many innocuous but telling moments in the meandering path toward deregulation.

As early as 1967, First Chicago Bank, operating in Illinois, tried to open a check-cashing office a short distance from its sole office. In Illinois banks were not allowed to have any branches. The rules rigidly prohibited them from having more than one office. This was to prevent them from taking advantage of economies of scale, and so prevent them from acquiring excessive economic power. The judge, interpreting the law correctly, denied their request. So they created entirely new banks and opened them at the locations where they had previously sought to open branches. In that way First Chicago achieved its aim, and made one of the earliest "back door" exceptions to the prevailing regulations against branching.

That early exception was followed by many more. After 1970 it became possible to create a financial holding company that included several types of non-bank financial intermediaries. Each holding company also held a federally-chartered commercial bank These bank holding companies became known as "financial supermarkets" because they offered such a wide range of products and services. They enjoyed the benefit of membership in the Federal Reserve system, with access to the lender of last resort; and they also allowed the holding company to use higher leverage than would have been 
permitted if all the lines of business had been consolidated on the federally-chartered bank's books.

Deregulation continued, sometimes for ad hoc reasons or for expediency. One way the barriers to interstate banking were relaxed was when regulators allowed a bank from outside a jurisdiction or regulatory district to buy a bank that was failing. The social objective of keeping banking local gave way little by little to pressures to consolidate and centralize. The Congress codified deregulatory guidelines in several landmark laws. The Depository Institutions Deregulation and Control Act of 1980 allowed more bank mergers than previous rules had allowed. Another landmark was the formal repeal in 1999 of the Glass Steagall law. Famously, prior to the 1929 stock market crash, the relationship between investment banking and commercial banking had been too cozy. The Congress evidently decided that the demarcation had already been blurred and was no longer a source of moral hazard.

There were more changes that undermined the thrifts, and a few that helped them. Regulation Q is a good example. It capped the rates that banks could pay on savings deposits, and so it neutralized the advantage that big city depository institutions might have had. It also prohibited paying interest on checking account deposits. As an illustration of the push and pull of regulation, thrifts were allowed to pay interest on checking account deposits as early as 1974 in New England. By then, however the process of disintermediation (as Gurley and Shaw called it in their classic 1960 book) was nibbling away at the thrifts' deposits. Money market mutual funds could circumvent the ceiling on deposit rates, so when inflation rose sharply, the non-bank financial intermediaries were able to take advantage and win market share.

Consolidation and conglomeration also were allowed. For a revealing indicator of how many bank mergers were allowed, a simple graph of the number of banks and thrifts is given below. The total peaked at over 18,000 in the early Eighties, and has fallen to about a third as many since then. This decline was partly due to bank and thrift failures. Those happened in waves, most notably in the 1980-82 time frame, when high interest rates hit the income statements of many thrifts. Their net interest margins went negative, and their equity bled away, and they could not continue as independent entities.

Another way that thrifts disappeared was by converting cooperative ownership structures into common stock ownership. During the Great Depression, many mutual savings banks and cooperative savings banks came into existence. These belonged to their depositors, and from time to time would pay dividends to depositors in addition to the interest they paid to depositors. This heirloom form of organization worked well, but the ups and downs of the stock market occasionally created opportunities for converting these cooperative banks into common stock ownership. It was then possible, during times when shares of financial institutions traded above book value per share, to convert a cooperative bank and obtain a windfall gain by selling the shares to the public. That quirky attribute proved to be the downfall of the cooperative and mutual savings banks. After the conversion, these community banks continued to serve their local communities, but were often acquired by larger financial institutions headquartered in bigger cities. These formerly independent lenders then had less autonomy 
and less latitude to operate according to their traditional rules of thumb.

There was another convention that contributed to the demise of many thrifts. This is a rule that makes sense but can have an unintended effect. The thrifts were required to mark their portfolios of mortgage loans to market. Their practice had been "book value" accounting for mortgage loans that were in good standing. Thrifts carried the loans on their books showing the remaining principal balance due. As the homeowners paid off the mortgages, the thrifts would report that the value of each loan was equal to the remaining principal due. During a period of high interest rates, that accounting convention would overvalue the loans, because in the event that the thrift tried to sell the loans, it would obtain much less than the remaining principal amount.

In the late Seventies and early Eighties, the need arose to sell mortgage loans that were in good standing. The thrift that originated the loan was failing, and needed to be liquidated or forcibly merged. The secondary market for mortgage loans treated them like corporate bonds, and valued them according to the present value of the remaining steam of payments. During those stressful days when short-term interest rates rose above $18 \%$, dealers would not pay the conventional book value figure for the loans. The failing thrift was not only illiquid but insolvent. So the depositors had to be paid from deposit insurance. If too many thrifts had failed, the deposit insurance fund would have been exhausted, and the U.S. Treasury would have had to step in to pay off the depositors. The potential consequences were too grave, so the thrifts, along with the commercial banks and every other financial services firm, were required to mark their portfolios to market. That rule was a blow to the classic design of the thrifts, and it also encouraged them to sell the loans promptly after originating them, instead of holding the loans to maturity as they had customarily done for decades.

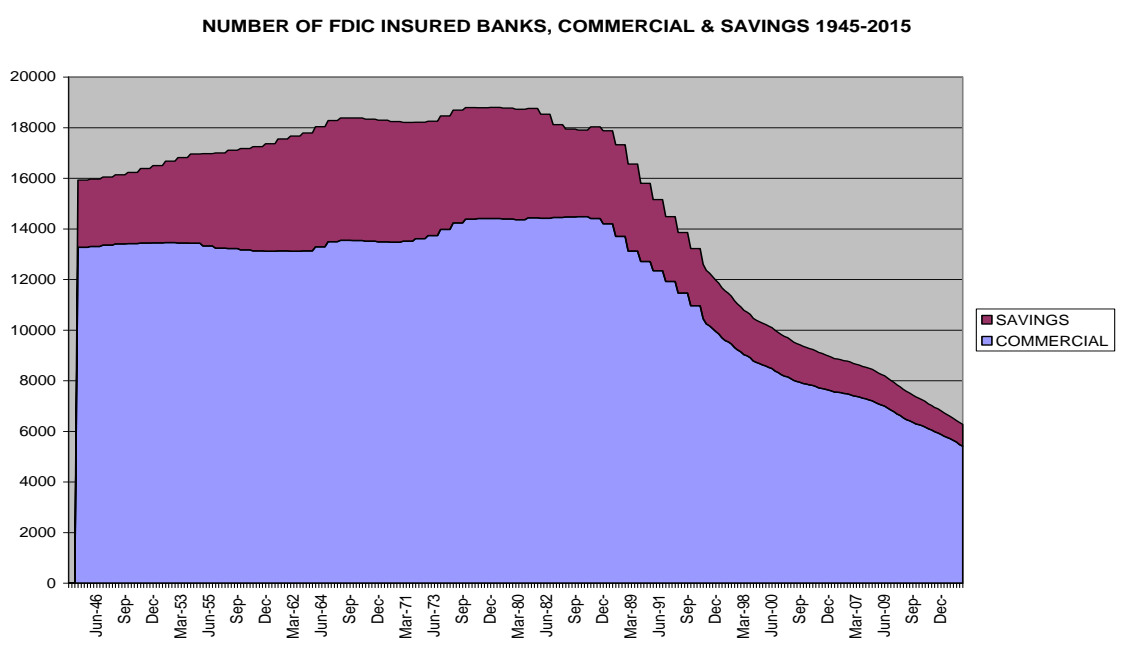

Figure 3. Number of FDIC Insured Banks, Commercial \& Savings 1945-2015

Seeing how the number of commercial banks and thrifts declined, an observer might think that the total deposits of banks and thrifts might have declined. But what really happened was that deposits rose 
while the number of deposit-taking institutions shrank, and the average size of banks and thrifts grew.

BANK DEPOSITS, COMMERCIAL \& SAVINGS, 1945-2015

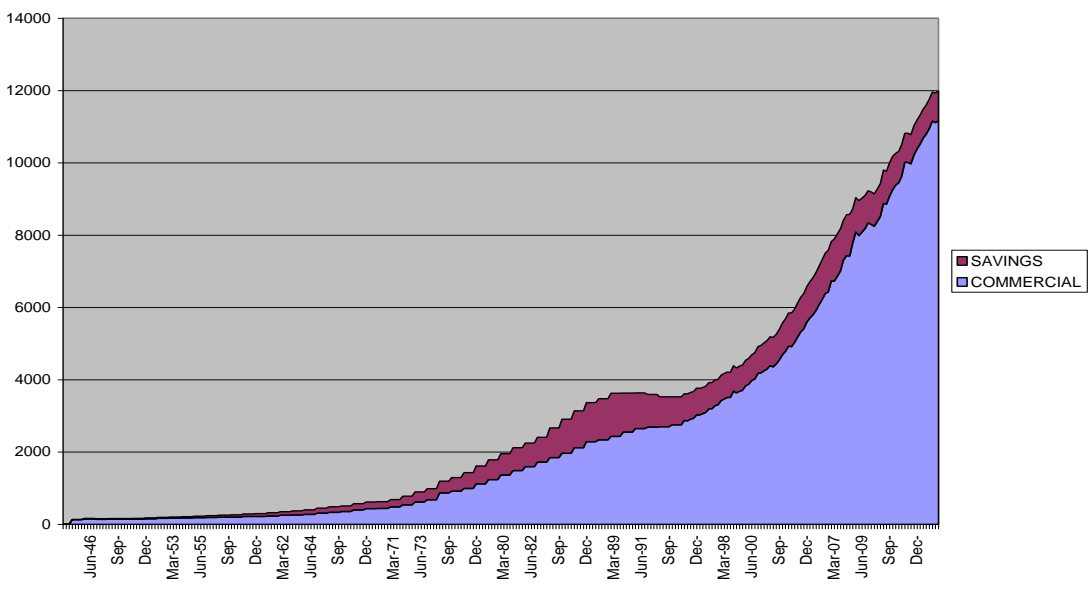

Figure 4. Bank Deposits, Commercial \& Savings, 1945-2015

The result was they borrowers who went to their friendly local bank or thrift found that there was still an office there, or in the next town, but it was not the small institution that it had been years earlier. Instead it was a branch of a larger, less personal institution.

The major change from the savings bank era, in terms of the effect that the change had on the "high touch" conventions of traditional mortgage lending, was securitization. Lenders stopped keeping the loans in their portfolios, first as a way to steer clear of the maturity mismatch that had doomed many old-style thrifts. Then they found that they could originate loans intending to sell them. If the loans met the mandated criteria, the thrift or the commercial bank could sell the loans to Fannie Mae and Freddie Mac, and those agencies would guarantee the payments. The secondary mortgage market mushroomed, partly because the mortgages were guaranteed, and partly because mortgage loans are good raw material for finance experts who use them to create bonds with attributes that appeal to investors.

The securitization era had advantages versus the savings bank era, but it had fatal flaws that are now well known. We do not enumerate the flaws, because they are well known and more than adequately summarized elsewhere.

\section{The Post-Crisis-Prudence Era}

In the immediate aftermath of the crisis, opportunistic buyers who had cash stepped in. The evidence is that home buyers did not use as much mortgage financing as they did during pre-crisis periods. Since 2009 a large percentage of home purchases have been for cash. As the recovery has progressed, a lower portion of sales have been for cash. For example, in November 2014, 36.1\% of home purchases were for cash. That is down from the peak of January 2011, when $46.4 \%$ of house purchases were for cash. The low rate of conventionally financed purchases indicates low participation by middle-class families and high participation by vulture investors and speculators. It also indicates that housing finance had 
suffered setbacks that curtailed or interrupted the supply of credit to conventional buyers.

Lenders who were able to operate during the post-crisis era were well advised to be ultra-prudent. They could not be certain what the capital adequacy requirements would be, nor what risk weightings might be assigned to loans in their portfolios. They were also wary of selling loans, knowing that the days of non-recourse sales have ended. Any loan that went into default was very likely to be sent back to the originating institution, with a formal request for full restitution. So lenders could not make as many loans as their equity capital previously could support.

\section{Conclusion}

The chaotic pattern that we have reviewed has been going on for almost a full century. The estimates of lost GDP presented in the second paper in this series show how pernicious the volatility has been. In view of the erratic performance, and the lost GDP, it is appropriate to propose and debate reforms to the ways the U.S. financial system finances this important sector of the economy.

\section{References}

Christopher, M., \& Ellen, W. (2010). Housing Characteristics. Census Briefs. Epstein, Gene. (2016, February 29). Homeownership Ready to Rise. Barrons, 30.

First Chicago is denied a new branch office. (1967). Retrieved from http://www.law.justia.com/cases/federal/appellate-courts/F2/380/909/315148/

Florida land boom. (1921-1926). Retrieved from http://www.library.hbs.edu/hc/crises/forgotten.html Gurley, \& Shaw. (1960). Money in a Theory of Finance. Brookings Institution.

Rate of Home Ownership USA. (1890-2000). Retrieved from https://www.census.gov/hhes/www/housing/census/historic/owner.html

Richard, K. G., \& Susan, M. W. (2005). The American Mortgage in Historical and International Context. Penn Institute for Urban Research.

William, E., \& Bryan, N. (2002). Mortgage Boom and Bust Affected Different Age Groups Differently. Federal Reserve Bank of St. Louis. 